\title{
PERAN DAN FUNGSI FILSAFAT ILMU DALAM PERKEMBANGAN \\ ILMU PENGETAHUAN BERLANDASKAN NILAI KEISLAMAN
}

\author{
Darliana Sormin, MA \\ anamuthmainnah82@gmail.com \\ ( Dosen Prodi PAI, Fakultas Agama Islam, UMTS)
}

\begin{abstract}
Science is a provision that is very important for human life because human life requires knowledge to be able to adapt to everything that exists in the surrounding environment. Science is also something that distinguishes creatures that have been created by God, among others, humans and animals, humans themselves are different that is given the potential (reason) that is more than other creatures to be able to master and menumbuhkembangkan science. Therefore, by seeing and knowing that science is something that is very important to have roles and functions in human life. In the life of the prime capital world to be safe and prosperous it must have knowledge, with the human sciences can manage, manage and utilize the natural resources God has created to meet the primary needs of human beings. Therefore humans are called as khlaifah in the earth so that humans can arrange as well as possible for the welfare of mankind.
\end{abstract}

Keywords: Roles, Functions, Philosophy, Science, Development, Science, Values, Islamization

\section{A. Pendahuluan}

Manusia begitu ia dilahirkan tidak tahu dan tidak mengenal dengan apaapa yang ada di sekitarnya, bahkan dengan dirinya sendiri. Ketika manusia mulai mengenal dirinya, kemudian mengenal alam sekitarnya, karena manusia adalah makhluk yang berpikir, maka dari itu mulailah ia berpikir dari mana asal sesuatu, bagaimana sesuatu, untuk apa sesuatu. Membicarakan masalah ilmu pengetahuan dan filsafat, kita akan memperoleh berbagai pengetahuan dan hikmat. Karena ilmu akan memberikan kepada kita pengetahuan dan filsafat akan memberi kita hikmat.

Abad ke 20 ini sering disebut abad ilmu (ilmu pengetahuan) dan teknologi, dalam perkembangannya telah dilemparkan kritik bahwa ilmu pengetahuan dan teknologi telah dikembangkan demi kesejahteraan umat 
manusia, namun ternyata berkembang secara ironis dan telah menjadi alat untuk merusak manusia itu sendiri. Dalam hal ini banyak disebut akibat jatuhnya bom atom di Hirosima, penggunaan senjata kimia di medan perang, seperti di Vietnam dan Afganistan, begitu juga pembuatan nuklir secara besar-besaran serta peluru kendali antar benua yang memungkinkan semua ini bisa menghancurkan manusia dengan segala aspek-aspeknya. Namun lepas dari semua kekhawatiran ini, di sisi lain ilmu mempunyai peranan dalam membantu mencapai kehidupan manusia sejahtera.

Ilmu dengan segala tujuan dan artinya sampai batas-batas tertentu telah banyak membantu manusia dalam mencapai tujuan hidup yaitu kehidupan yang lebih baik. Walaupun kebenarannya tidak mencapai kebenaran mutlak, tetapi dalam keterbatasannya ia membantu kehidupan dan kepentingan manusia di dunia yang fana ini, sesuai dengan bidang masing-masing. Pengalaman manusia tidak pernah sempurna, pengetahuannya tumbuh dan berkembang sepanjang masa. Ilmu menghasilkan teknologi, yang memungkinkan manusia dapat bergerak atau bertindak dengan cermat dan tepat karena ilmu dan teknologi merupakan hasil kerja pengalaman, observasi, eksperimen dan verifikasi.

Ilmu dan teknologi yang manusia punyai bisa untuk mengubah wajah dunia dimana manusia itu sendiri tinggal, mengubah cara manusia itu sendiri bekerja, dan cara manusia berfikir. Dengan ilmu dan teknologi manusia dituntut untuk mengadakan perubahan secara terus menerus, perbaikan, serta penemua-penemuan baru. Perkembangan Industri, perkembangan sodial budaya, dan perkembangan Industri persenjataan merupakan suatu pertanda bahwa ilmu dan teknologi akan terus berkembang.

\section{B. Peran dan Fungsi Filsafat Ilmu}

Filsafat berasal dari bahasa Yunani yang tersusun dari dua kata, yaitu Fhilos dan Sophia. Filos berarti senang, gemar atau cinta, sedangkan Sophia dapat diartikan sebagai kebijaksanaan. Dengan begitu filsafat dapat diartikan sebagai suatu kecintaan kepada kebijaksanaan. (Harun Nasution, 1997: 2). Di 
dalam khazanah pemikiran keIslaman di mana kata shopos itu disepadankan dengan kata himah, sehingga filsafat bisa berarti kecintaan kepada hikmah atau di dalam kata kerja ia bisa berarti cinta hikmah: mencintai himah.

Demikian juga halnya arti filsafat di dalam khazanah pemikiran Islam juga dapat diartikan dengan ilmu yang menyeluruh atau ilmu yang secara garis besar berbicara mengenai segala sesuatu yang wujud dan yang mungkin wujud serta juga membicara tentang hukum kausalitas, sebabakibat yang terjadi dari yang wujud itu sehingga mendatangkan keyakinan dan kepercayaan. (Osman Bakri, 2000: 102). Maka oleh karena itu dengan secara ringkas juga dapat dikatakan bahwa filsafat adalah pengetahuan universal yang membicarakan mengenai segala sesuatu yang ada dan wujud dari yang ada tersebut. Pemakaian kata ilmu itu di dalam bahasa Indonesia dapat disejajarkan dengan istilah science. Science adalah kata yang berasal dari bahasa Latin: Scio, cire yang berarti pengetahuan. (Sidi Gazalba, 1992: 39).

Berkaitan dengan masalah ilmu pengetahuan George Thomas White Patrick pernah mengatakan bahwa science is the complete and consistent discreptions of the facts of experience in the simples possible term (ilmu adalah sesuatu yang bersifat menyeluruh dan mencakup semua diskripsi/ penjelasan fakta-fakta yang diambil atau diterima dari suatu pengalaman dalam pengertian yang sangat simpel/sederhana). (George Thomas White Patrick,1986: 20).

\section{Peran Filsafat Ilmu}

Ada sebuah cerita filosof Plato terhadap muridnya yang sampai mengeluarkan muridnya disebabkan karena pertanyaan muridnya tentang apakah kegunaan pelajaran matematika yang telah diajarkan plato. Pada waktu itu pengetahuan-pengetahuan, termasuk juga ilmu memang tidak mempunyai kegunaan praktis melainkan estetis, artinya seperti kita mempelajari main piano atau membaca sajak cinta, maka pengetahuan ini lebih menunjukkan pada kepuasan jiwa, dan juga sebagai konsep untuk memecahkan masalah. Bahkan sekarangpun gejala ini masih terlihat di mana orang mempelajari berbagai pengetahuan ilmiah bukanlah sebagai 
teori yang mempunyai kegunaan praktis melainkan sekedar upaya untuk memperkaya jiwa. (Jujun S. Suria Sumantri, 1990: 364).

Penempatan ilmu dalam dalam fungsi estetis pada zaman Yunani Kuno itu disebabkan filsafat mereka yang memandang rendah pekerjaan yang bersifat praktis yang waktu itu dikerjakan oleh budak belian. Menurut pandangan mereka, merupakan sesuatu yang kurang pada tempatnya kalau kaum yang merdeka memikirkan masalah yang tidak sesuai dengan status sosial mereka. (Jujun S. Suria Sumantri, 1990: 365). Prediksi yang salah inilah yang sebenarnya menyebabkan perkembangannya kebudayaan menghafal pada sistem pendidikan kita. Ilmu tidak berfungsi sebagai pengetahuan yang diterapkan sebagai pemecahan masalah sehari-hari, melainkan sekedar dikenal dan dikonsumsi.

Kerlinger dalam melihat fungsi ilmu, terlebih dahulu mengelompokkan dua sudut pandang tentang ilmu yaitu pandangan statis dan pandangan dinamis. Dalam pandangan statis, ilmu merupakan aktifitas yang memberikan sumbangan bagi sistematisasi informasi bagi dunia. Tugas ilmuan adalahmenemukan fakta baru dan menambahkannya pada kumpulan informasi yang sudah ada, oleh karena itu dianggap sebagai sekumpulan fakta, serta merupakan suatu cara menjelaskan gejala-gejala yang diobservasi, yang berarti bahwa dalam pandangan ini penekanannya terletak pada keadaan pengetahuan/ilmu yang ada sekarang serta upaya menambahkannya baik hukum, prinsip atau teori. Dalam pandangan ini fungsi ilmu bersifat praktis yakni sebagai disiplin atau aktivitas untuk memperbaiki sesuatu, membuat kemajuan, mempelajari fakta serta memajukan pengetahuan untuk memperbaiki sesuatu (bidangbidang kehidupan). (Uhar Suhar Saputra, 2004: 50).

Selanjutnya pandangan dinamis atau pandangan heuristik (menemukan), dalam pandangan ini ilmu dapat dilihat lebih dari sekedar aktivitas, penekananya terutama pada teori dan skema konseptual yang saling berkaitan. Dalam pandangan ini fungsi ilmu adalah untuk 
membentuk hukum-hukum umum yang melengkapi prilaku dari kejadiankejadian empiris atau objek empiris yang menjadi perhatiannya sehingga memberikan kemapuan berhubungan berbagai kejadian yang terpisahpisah serta dapat secara tepat memprediksikan kejadian-kejadian masa datang. (Uhar Suhar Saputra, 2004: 51).

Dengan memperhatikan penjelasan di atas ilmu mempunyai fungsi yang sangat penting bagi kehidupan manusia, ilmu dapat membantu untuk memahami, menjelaskan, mengatur dan memprediksi kejadian baik yang bersifat keAlaman atau sosial yang terjadi dalam kehidupan manusia. Setiap masalah yang ada dalam kehidupan manusia selalu berupaya untuk dipecahkan agar dapat dipahami, dan setelah itu menjadi mampu untuk mengaturnya serta dapat memprediksikan kemungkinan yang akan terjadi berdasarkan pemahaman yang dimilikinya, dan dengan kemampuan prediksi tersebut maka perkiraan masa depan dapat didesain dengan baik meskipun hal itu bersifat probanilistik, mengingat dalam kenyataannya sering terjadi hal-hal yang bersifat unpredictable.

Dengan demikian tujuan dari ilmu adalah memahami, mempredikisi, dan mengatur berbagai aspek kehidupan di dunia, di samping untuk menemukan atau memformulasi teori, dan teori itu sendiri pada dasarnya merupakan penjelasan tentang sesuatu sehingga dapat memperoleh kefahaman, dan dengan kepahaman maka prediksi kejadian dengan probabilitas yang cukup tinggi asalan teori tersebut telah teruji kebenarannya.

\section{a. Penerang (Eksplaining)}

Eksplaining berasal dari bahasa inggris dari kata eksplain yang berarti menerangkan dan menjelaskan. Ilmu dapat berfungsi sebagai penjelas untuk menerangkan segala sesuatu yang ada disekitar manusia. Penjelas suatu teori dapat dibedakan menjadi empat jenis, yaitu : deduktif, probalistik, fungsionil, dan genetik. Penjelasan deduktif menggunakan penalaran deduktif untuk 
menjelaskan suatu gejala dengan menarik kesimpulan yang logis dari premis-premis yang telah diketahui hubungannya terlebih dahulu. Pejelasan probalistik ialah penjelasan yang menggunakan penalaran induktif untuk menjelaskan suatu gejala dengan menarik generalisasi dari sejumlah kasus dan fakta, dimana generalisasi bersifat peluang yang dapat berupa kemungkinan dan kemungkinan itu hampir dapat dipastikan. Penjelasan fungsional ialah penjelasan yang meletakkan suatu objek penyelidikan pada tempat tertentu dalam kaitannya dengan sistem secara keseluruhan yang mempunyai karakteristik atau arah perkembangan tertentu. Sedangkan penjelasan genetik ialah penjelasan yang didasarkan faktor-faktor genetik yang telah ada sebelumnya. (Widia Fitri, 2004: 14).

\section{b. Pengira (Predicting)}

Ilmu bagi kehidupan manusia dapat berperan sebagai pengira terhadap suatu fenomena yang ditemui oleh manusia tersebut. Ilmu yang dimiliki oleh manusia telah terwujud dalam berbagai bentuk teori-teori yang ada. Teori biasanya menerangkan hubungan dua variable atau lebih dalam suatu hubungan kausalitas. Teori adalah pengetahuan ilmiah yang memberi penjelasan terhadap pertanyaan "mengapa". Teori yang ada tersebut memberi manfaat kepada untuk memperkirakan sesuatu kemungkinan yang akan terjadi, misalnya berkaitan dengan ilmu astronomi, dapat membantu manusia untuk memprediksi kemungkinan terjadi gerhana. Contoh lain adalah teori ilmu alam mengatakan bila besi dipanaskan, maka besi itu akan memuai, maka dari pernyataan ini telah dapat dipahami dan mengira kenapa setiap yang berjenis logam ketika dipanaskan memuai. (Widia Fitri, 2004: 16). Itulah ilmu yang mempunyai peran sebagai pengira suatu keadaan atau kejadian. 


\section{c. Pengatur (Controling)}

Ketika manusia sudah mampu untuk meramal sesuatu yang akan terjadi dengan berpijak kepada ketentuan ilmu, maka fungsi control dapat dijalankan. Hal ini bertujuan untuk mencegah hal yang tidak diinginkan. Misalnya pada masalah gempa bumi dengan kekuatan 7,1 SK ketika manusia mengetahui ilmu yang berkaitan dengan geofisika, manusia dapat memperkirakan akibat yang mungkin terjadi dikarenakan gempa tersebut apakah akan menimbulkan tsunami atau tidak. Sehingga manusia dapat mengatur apa yang harus dilakukannya sebelum hal itu terjadi untuk mengantisipasi terjadinya musibah yang sangat besar.

\section{d. Pemberdaya (Empowering)}

Dengan adanya ilmu, maka maka sesuatu yang dulunya tidak bermanfaat dapat di dayagunakan untuk kesejahteraan hidup manusia. Manusia dengan berbagai disiplin ilmu yang berhasil dikembangkannya, telah berhasil menemukan berbagai temuan untuk memanfaatkan segala sesuatu yang ada di sekitarnya dengan sebaik-baiknya. Misalnya saja, manusia sebelumnya tidak mengetahui bahwa tanaman bahwa suatu tanaman mempunya kasiat dan manfaat yang tinggi untuk kesehatan, setelah manusia mengetahui maka hal tersebut manusia memberdayakan dan menggunakan tanaman tersebut dengan sebaik-baiknya, dan melestarikannya sesuai dengan disiplin ilmu yang ada, baik mencangkoknya, kloning, rekayasa genetika dan lainya.

Jujun S Suria Sumantri dalam bukunya "Filsafat Ilmu" menyebutkan buku-buku ilmuan yang tebal itu pada hakikatnya sama saja dengan bukubuku primbon tukang ramal, yakni menjelaskan, meramal, dan mengontrol. Tentu saja yang berbeda adalah azas dan prosedurnya: menjelaskan, meramal, mengontrol inflasi kita yang menggunakan azas dan prosedur keilmuan, sedangkan menjelaskan, meramal, mengontrol telapak tangan kita menggunakan asaz dan prosedur perklenikan. Dengan 
demikian, tidak heran kalau dalam memecahkan masalah-masalah kehidupan orang yang tidak selalu datang pada ilmuan melainkan kepada dukun. Keduanya melakukan fungsi yang sama meskipun asas dan prosedurnya berbeda. Pilihan antara keduanya tergantung dengan kepercayaan kita, artinya dalam memecahkan masalah kehidupan, apakah kita mempercayai azas dan prosedur keilmuan atau perklenikan. Tingkat dan kepercayaan seseorang memang berbeda, kepercayaan seseorang tergantung kepada pendidikan, kepercayaan masyarakat tergantung pada kebudayaan. (Jujun S. Suriasumantri, 1990: 366-368).

\section{Fungsi Filsafat Ilmu}

Dalam pandangan Islam, ilmu tersebut mempunyai banyak fungsi diantaranya adalah :

a. Sarana paling utama menuju taqwa

Urgensi ilmu dalam kehidupan seorang mukmin yang bertaqwa adalah hal yang tidak dapat disangkal. Karena ketaqwaan itu sendiri identik dengan kemampuan merealisasikan ilmu yang benar bersumber dari alQur'an dan as-Sunnah sesuai dengan pemahaman salaful umah (umat terdahulu)

b. Amalan yang tidak terputus pahalanya

Ilmu merupakan sesuatu yang paling berharga bagi setiap muslim, sebab ilmu akan memelihara pemiliknya dan merupakan beban bawaan yang tidak berat, bahkan akan semakin bertambah bila diberikan dan diamalkan, serta merupakan amalan yang akan tetap mengalir pahalanya meskipun telah wafat.

c. Pondasi utama sebelum berkata dan beramal

Ilmu memiliki kedudukan yang penting dalam agama Islam, oleh karena itu ahli sunnah wal jama'ah menjadikan ilmu sebagai pondasi utama sebelum berkata-kata dan beramal sebagaimana disebutkan oleh Imam dalam Shahihnya dalam Bab ilmu sebelum berkata dan beramal. Berdasarkan firman Allah Swt : 


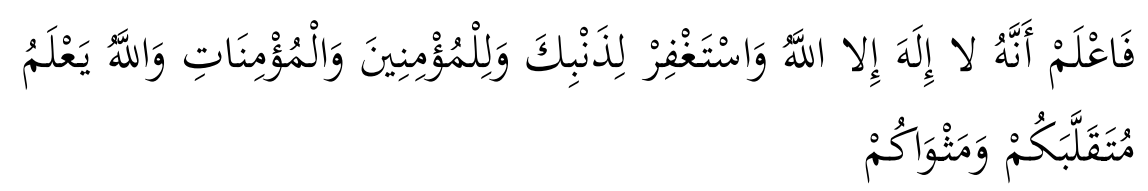

Artinya : "Maka ketahuilah, bahwa sesungguhnya tidak ada Tuhan (Yang Hak) melainkan Allah dan mohonlah ampunan bagi dosamu dan bagi (dosa) orang-orang mukmin, lakilaki dan perempuan. Dan Allah mengetahui tempat kamu berusaha dan tempat tinggalmu."(QS. Muhammad : 19)

Syaihk Shalih al-Usmani mengatakan : dengan ayat di atas imam Bukhari berdalil bahwa kita harus memulai dengan ilmu sebelum berkata dan beramal. Ini merupakan dalil naqli yang jelas bahwa manusia harus berilmu lebih dahulu sebelum ia beramal dan berkata.

d. Sebagai kebutuhan rohani

e. Salah satu bentuk metode tarbiyah bagi umat agar tidak menjadi alat permainan iblis

\section{Perkembangan Ilmu Pengetahuan Berlandaskan Nilai KeIslaman}

Dalam perspektif sejarah, perkembangan ilmu-ilmu keislaman mengalami pasang surut. Suatu ketika mencapai puncak kejayaan, dan di saat yang lain mengalami kemunduran. Kajian berikut akan menjelaskan fenomina tersebut serta faktor-faktor yang mempengaruhi. Sejarah politik dunia Islam biasanya dipetakan ke dalam tiga periode, yaitu; periode klasik (650-1250 $\mathrm{M})$, periode pertengaha (1250-1800 M), dan periode modern (1800-sekarang). (Harun Nasution, 1975: 13-14).

Dari ketiga periode tersebut, yang dikenal sebagai masa keemasan Islam adalah periode klasik, yang-antara lain-ditandai dengan etos keilmuan yang sangat tinggi, yang ditunjukkan dengan pesatnya perkembangan ilmu pengetahuan di berbagai bidang kehidupan. Akselerasi perkembangan ilmu pengetahuan di dunia Islam sangat tampak setelah masuknya gelombang Hellenisme melalui gerakan penerjemahan ilmu-ilmu pengetahuan Yunani ke dalam bahasa Arab, yang dipelopori khalifah Harun 
al-Rasyīd (786-809 M) dan mencapai puncaknya pada masa khalifah alMakmūn (813-833 M). Beliau mengirim utusan ke kerajaan Romawi di Eropa untuk membeli sejumlah manuscripts untuk kemudian diterjemahkan ke dalam bahasa Arab. (Harun Nasution, 1973: 11).

Selanjutnya perkembanngan ilmu pengetahuan berdasarkan nilai keislaman dimulai dari penerjemahan ilmu pengetahuan dan filsafat Yunani oleh umat Islam bersifat selektif dan kreatif. Yang diterjemahkan adalah filsafat dan ilmu-ilmu yang memberikan kemaslahan bagi umat seperti; kedokteran, pertanian, astronomi, ilmu bumi, ilmu ukur, dan ilmu bangunan. Sedangkan sastra Yunani ditinggalkan karena banyak berbau takhayul dan syirik. Dan ilmu-ilmu terjemahan tersebut tidak diterima begitu saja (taken for granted), melainkan dikembangkan dan diislamkan, mengingat pertumbuhan ilmu-ilmu Yunani Kuno bersifat sekuler. Oleh karena itu, perkembangan ilmu dalam Islam sangat berbeda dengan yang berkembang di Yunani. Bahkan menurut Max I. Dimont, ahli Sejarah Peradaban Yahudi dan Arab, peradaban Islam jauh meninggalkan peradaban Yunani. Dimont, sebagaimana dikutip Nurcholish Madjid, memberikan ilustrasi :'Dalam hal ilmu pengetahuan, bangsa Arab [muslim] jauh meninggalkan bangsa Yunani. Peradaban Yunani itu, dalam esensinya, adalah ibarat sebuah kebun subur yang penuh dengan bunga-bunga indah namun tidak banyak berbuah. Peradaban Yunani itu adalah suatu peradaban yang kaya dalam filsafat dan sastra, tetapi miskin dan teknik dan teknologi. (Nurcholish Madjid, 1997: 67). Karena itu merupakan suatu usaha bersejarah dari bangsa Arab dan Yunani Islamik (yang terpengaruh oleh peradaban Islam) bahwa mereka mendobrak jalan buntu ilmu pengetahuan Yunani itu, dengan merintis jalan ilmu pengetahuan baru menemukan konsep nol, tanda minus, bilangan-bilangan irasional, dan meletakkan dasar-dasar ilmu kimia baru yaitu ide-ide yang meratakan jalan ke dunia ilmu.

Pesatnya perkembangan ilmu pengetahuan di era klasik, setidaknya disebabkan oleh beberapa faktor, yaitu; pertama, etos keilmuan umat Islam yang sangat tinggi. Etos ini ditopang ajaran Islam yang memberikan perhatian 
istimewa terhadap ilmuwan dan aktivitas ilmiah. Kedua, Islam merupakan agama rasional yang memberikan porsi besar terhadap akal. (Harun Nasution, 1997: 11). Semangat rasional tersebut semakin menemukan momentumnya setelah umat Islam bersentuhan dengan filsafat Yunani klasik yang juga rasional. Kemudian, melalui aliran teologi rasional Mu'tazilah, para ilmuwan memiliki kebebasan yang luar biasa dalam mengekspresikan pikiran mereka untuk mengembangkan ilmu pengetahuan. Ketiga, berkembangnya ilmu pengetahuan di kalangan umat Islam klasik adalah sebagai dampak dari kewajiban umat Islam dalam memahami alam raya ciptaan Allāh. Dalam alQur'ān dijelaskan bahwa alam raya diciptakan untuk kepentingan manusia. Untuk itu alam dibuat lebih rendah (musakhkhar) dari manusia sehingga terbuka dipelajari, dikaji, dan diteliti kandungannya. Keempat, di samping alasan di atas, perkembangan ilmu pengetahuan di era klasik juga ditopang kebijakan politik para khalifah yang menyediakan fasilitas dan sarana memadai bagi para ilmuwan untuk melakukan penelitian dan pengembangan ilmu.

\section{Peran dan Fungsi Filsafat Ilmu dalam Perkembangan Ilmu Pengetahuan Berlandaskan Nilai KeIslaman}

Manusia mempunyai kriteria yang istemewa, yaitu kemampuan untuk berfikir yang ada dalam satu struktur dengan perasaan dan kehendaknya. Pemikiran manusia itu mengalami perkembangan, mulai dari ia mengenal sesuatu, kemudian berfikir kritis mengenai makna tentang sesuatu yang difikirkannya tersebut. Pengenalan manusia kemudian berkembang semakin kreatif, kreatifitas ini memungkinkan manusia untuk menciptakan seperti membuat makanan, minuman, pakaian dan lain-lain dengan memanfaatkan sumber daya alamnya, termasuk juga menciptaan suatu kelompok sosial yang sering terdengar organisasi.

Manusia di dalam kehidupannya mempunyai tujuan yang lebih tinggi dari sekedar kehidupannya. Inilah yang menyebabkan manusia mengembangkan ilmu pengetahuan sehingga mendorong manusia menjadi 
makhluk yang bersifat khas di muka bumi ini, yang mampu berfikir dan nalar. Sutriono dan Rita Hanafi, 2007: 39).

Manusia pada dasarnya memiliki berbagai potensi. Dalam perspektif Islam, potensi atau fitrah dapat dipahami sebagai kemampuan atau hidayah yang bersifat umum dan khusus diantaranya:

1. Hidayah Wujdaniyah, yaitu potensi manusia yang berwujud insting atau naluri yang melekat dan langsung berfungsi pada saat manusia dilahirkkan di muka bumi

2. Hidayah Hisysyiyah, yaitu potensi Allah yang diberikan kepada manusia dalam bentuk kemampuan indrawi sebagai penyempurnaan hidayah wudiyah

3. Hidayah Aqliyah, yaitu potensi akal sebagai penyempurna dari kedua hidayah di atas

4. Hidayah Diniyah, yaitu petunjuk agama yang diberikan kepada manusia yang berupa keterangan tentang hal yang menyangkut keyakinan dan aturan

5. Hidayah Taufiqiyah, yaitu hidayah yang sifatnya khusus. (Ramayulis dan Samsul Nizar, 2009: 170).

Satu yang membedakan agama Islam dengan yang lainnya adalah penekanannya terhadap masalah ilmu. Al-Qur'an dan Sunah mengajak umat muslim untuk mencari dan mendapatkan ilmu dan kearifan, serta menempatkan orang-orang yang berpengetahuan pada derajat yang tinggi. Ayat pertama turun surah Al-A'laq 1-5 yang diwahyukan kepada Rasulullah Saw menyebutkan pentingnya membaca dan suatu ajaran untuk manusia yaitu, (Mahdi Ghulsyani,1998: 39):

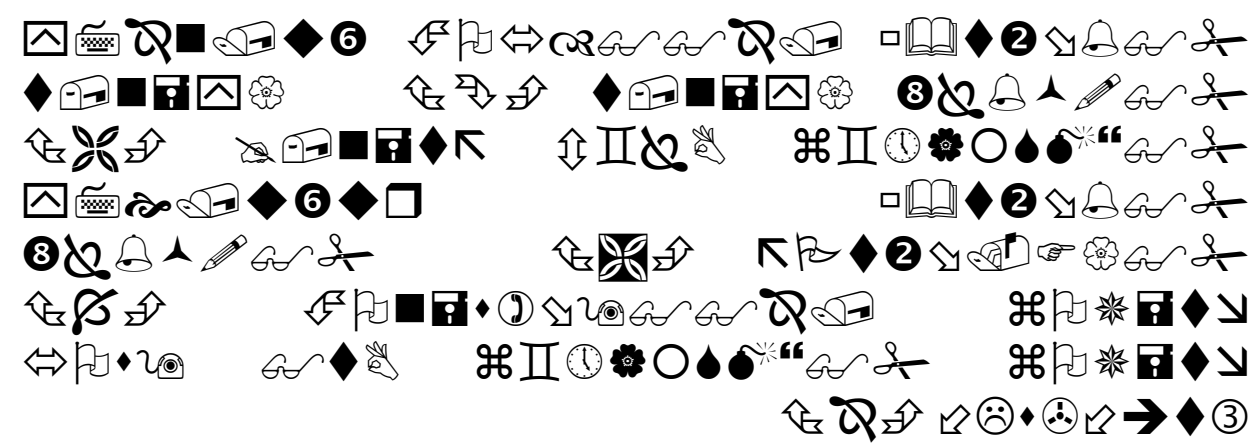


Yang artinya: "Bacalah dengan menyebut nama Tuhanmu yang menciptakan, dia telah menciptakan manusia dari segumpal darah. Bacalah, dan Tuhanmu lah yang maha pemurah, yang mengajar manusia dengan perantara kalam. Dia mengajarkan manusia apa yang tidak ia ketahuinya".

Dan tentang penciptaan Nabi Adam, Al-Qur'an mengatakan bahwa malaikatpun disuruh bersujud di hadapan Adam setelah ia diajari nama-nama:

$\Delta$ 凤回(10\& Ho

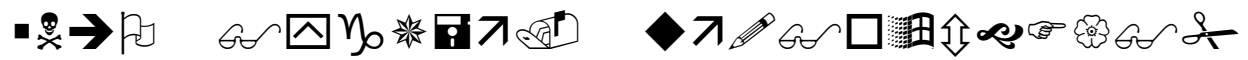
(7םL

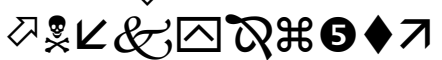

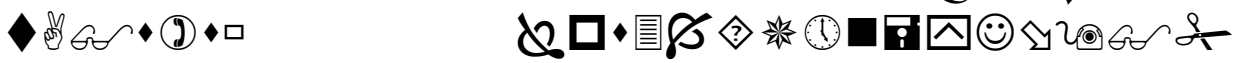
¿त

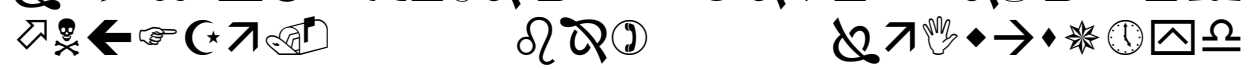

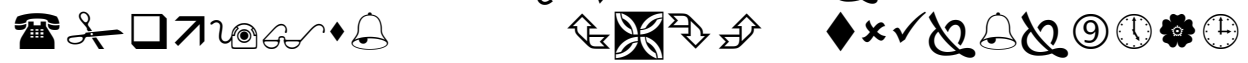

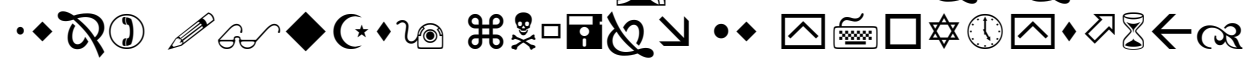

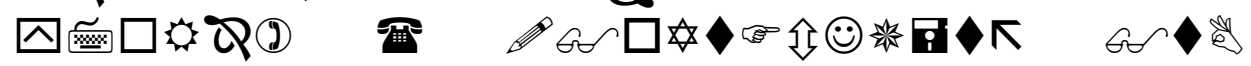

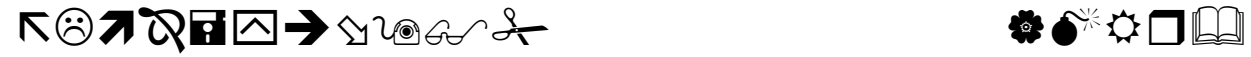

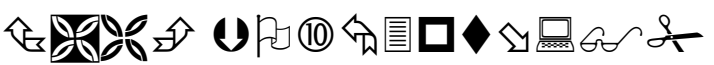

Artinya: "Dan Dia mengajarkan kepada Adam nama-nama (benda-benda) seluruhnya, kemudian mengemukakannya kepada para Malaikat lalu berfirman: "Sebutkanlah kepada-Ku nama benda-benda itu jika kamu memang orang-orang yang benar! Mereka menjawab: "Maha Suci Engkau, tidak ada yang kami ketahui selain dari apa yang telah Engkau ajarkan kepada kami; sesungguhnya Engkaulah Yang Maha Mengetahui lagi Maha Bijaksana."(QS. Al-Baqarah: 31-32)

Al-Qur'an mengatakan bahwa tidak sama, antara mereka yang mengatahui dengan mereka yang tidak mengetahui :

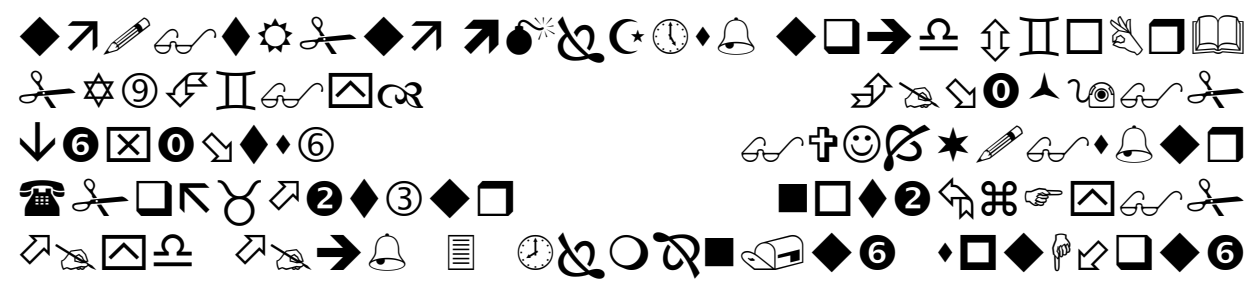



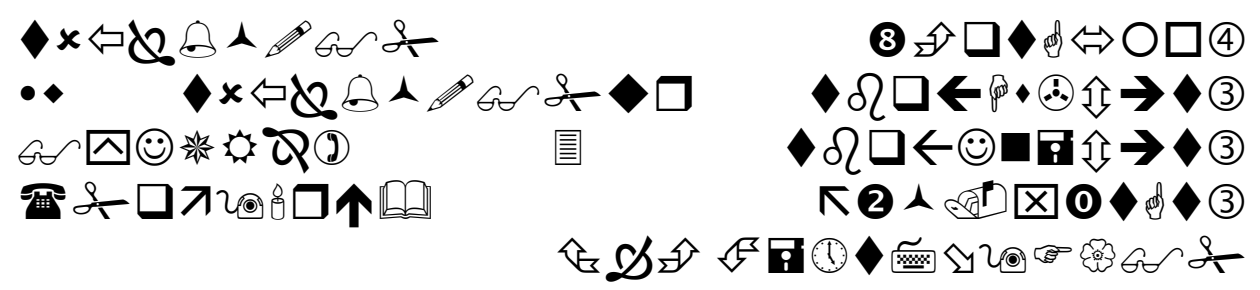

Artinya: "(Apakah kamu hai orang musyrik yang lebih beruntung) ataukah orang yang beribadah di waktu-waktu malam dengan sujud dan berdiri, sedang ia takut kepada (azab) akhirat dan mengharapkan rahmat Tuhannya? Katakanlah: "Adakah sama orang-orang yang mengetahui dengan orangorang yang tidak mengetahui?" Sesungguhnya orang yang berakallah yang dapat menerima pelajaran". (Qs. AzZumar: 9)

Dan kemudian Allah menyatakan hanya orang yang berlajarlah yang memahami :

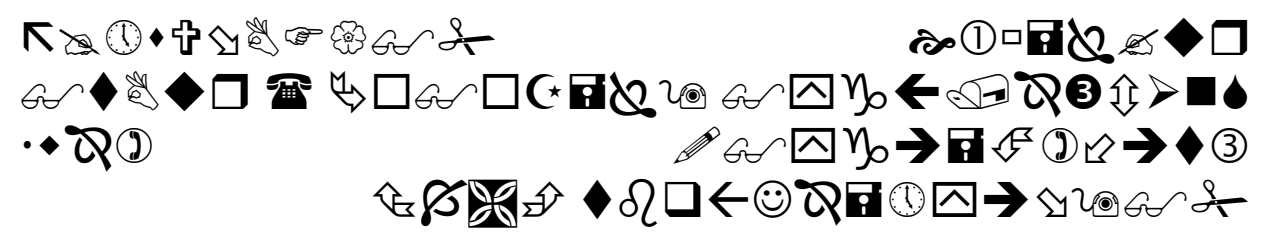

Artinya : "Dan perumpamaan-perumpamaan ini Kami buatkan untuk manusia dan tiada yang memahaminya kecuali orangorang yang berilmu." (QS. Al-Ankabut: 43)

Selanjutnya dalam sebuah hadis disebutkan:

$$
\text { الدين عقل لا دين لمن لا عقل له }
$$

Ungkapan itu memiliki arti bahwa Islam adalah agama akal (adalah tidak dibebani syari'at agama orang yang tidak berakal) AI-Hadits. Hal ini menunjukkan bahwa betapa Islam sangat menghargai akal fikiran manusia yang merupakan tempat menampung ilmu pengetahuan dan sekaligus ia yang membedakan antar manusia dengan makhluk yang disebut binatang. Di dalam Alquran cukup banyak ayat-ayat yang menunjukkan penghargaan Islam terhadap ilmu pengetahuan dan orangorang yang memilikinya. Sebagaimana ditegaskan Allah dalam surat 11 AI-Mujadalah ayat 11 yaitu:

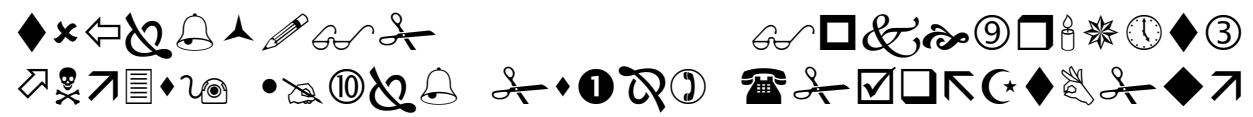


(6) $8 \times$

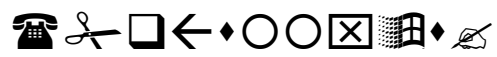
盗\&

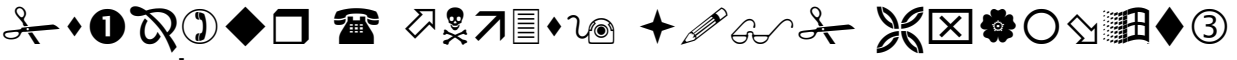
苗\& +o and 的

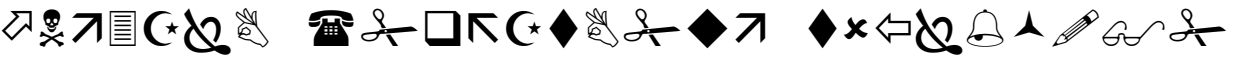

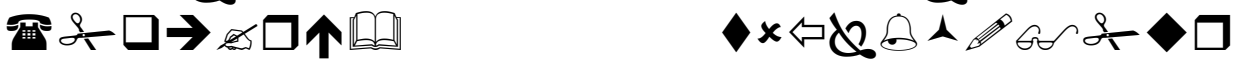
濖

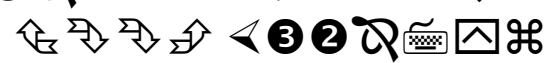

Artinya: Hai orang-orang beriman apabila kamu dikatakan kepadamu: "Berlapang-lapanglah dalam majlis", Maka lapangkanlah niscaya Allah akan memberi kelapangan untukmu. dan apabila dikatakan: "Berdirilah kamu", Maka berdirilah, niscaya Allah akan meninggikan orang-orang yang beriman di antaramu dan orang-orang yang diberi ilmu pengetahuan beberapa derajat. dan Allah Maha mengetahui apa yang kamu kerjakan.

Bahkan ayat-ayat yang pertama-tama turunpun memerintahkan manusia untuk membaca, membaca dan membaca, bukankah didalamnya dikandung maksud agar manusia itu belajar, berilmu dan tidak bodoh, dan agar nampak perbedaan antara manusia dengan jenis makhluk lainnya manusia dituntut untuk menggunakan akalnya. Hanya persoalannya, pengetahuan mana harus kita ketahui terlebih dahulu dan mana yang kemudiannya, dan apa sebenarnya yang dimaksud dengan pengetahuan itu? masalah ini sudah lama dipersoalkan. Socrates, Plato dan juga Aristoteles misalnya telah membahasnya secara panjang lebar. John Lock seorang filosof yang sangat banyak pengaruhnya setelah renaisans Eropa telah menjadikan teori pengetahuan sebagai pangkal tolak dan pusat diskusi filsafatnya. Bahwa ia menganggap keliru untuk membicarakan metafisika sebelum menyelesaikan teori pengetahuan. Menurutnya sebelum berpikir, masalahmasalah pemikiran itu harus diselesaikan terlebih dahulu. Sedangkan masalah pengetahuan yang menurutJohn Lock harus diawali dengan teori tersebut, menurut sejarah filsafat dapat diperoleh melalui beberapa sumber di antaranya:

a. Pengetahuan itu dibawa lahir bersama kelahiran manusia 
b. Diperoleh dari budi

c. Diperoleh dari indera-indera khusus yaitu pendengaran, penglihatan, ciuman, dan rabaan.

d. Berasal dari penghayatan langsung atau ilham.

Bentuk pengetahuan yang sangat sederhana adalah sekedar kesadaran, seperti apa yang berlangsung kepada suatu organisme ketika ia disinggung atau dipengaruhi oleh suatu obyek, apabila organisme mulai memberikan jawaban terhadap suatu ransangan, sesudah itu memberikan respons khusus terhadap suatu situasi, maka situasi itu mulai mengandung makna. Misalnya ia menarik, memberi harapan, atau mengancam. Hubungan yang timbal balik itu dapat disebut sebagai perkenalan. Sesudah itu datanglah bahasa dengan nama-nama barang dan kejadian, istilah yang abstrak, penilaian dan penuturan. Interaksi dengan lingkungan menghasilkan pengalaman. Pengalaman itu menjadi dasar dan dapat meningkat menjadi situasi baru tertentu. Situasi dapat diolah oleh budi, dikontrol atau dikuasai. Pengalaman dasar inilah yang kemudian disebut dengan pengetahuan, yang selanjutnya diklasifikasi, diungkapkan dengan bahasa, dan dikodifikasi dalam istilah-istilah ilmu.

Masalahnya tidak berhenti sampai di sini, sebab setelah orang memiliki apa yang disebutpengetahuan ia masih akan mempertanyakan apakah pengetahuan yang dimilikinya itu benar, dan apakah sebenarnya kebenaran itu? Dijelaskan di sini bahwa berbagai macam pengertian kebenaran akan menjadi jelas apabila kata itu kita hadapkan kepada lawannya dan kita susulkan artinya.

Beragam pengertian tentang kebenaran menggunakan lambang yang sama bahwa kebenaran adalah soal hubungan antara pengetahuan dan apa yang jadi obyeknya. Yaitu apabila terjadi persesuaian dalam hubungan antara obyek dan pengetahuan kita tentang obyek itu. Dengan demikian dapat ditarik suatu kesimpulan sementara bahwa masalah kebenaran adalah masalah hubungan antara ide-ide kita dengan dunia realitas. 


\section{E. Kesimpulan}

Dari Uraian di atas maka dapat ditarik beberapa kesimpulan yaitu:

1. Manusia pada dasarnya memiliki berbagai potensi. Dalam perspektif Islam, potensi atau fitrah dapat dipahami sebagai kemampuan atau hidayah yang bersifat umum dan khusus diantaranya: Hidayah Wujdaniyah, Hidayah Hisysyiyah, Hidayah Aqliyah, Hidayah Diniyah, dan Hidayah Taufiqiyah. Setiap potensi yang dimiliki manusia ini sangat membantu untuk dapat memunculkan berbagai macam ilmu di dalam kehidupan.

2. Ilmu mempunyai berbagai manfaat dan peran bagi kehidupa manusia antara lain :

a. Explaining (penerang)

b. Predicting (pengira)

c. Controling (pengatur)

d. Empowering (pemberdaya)

3. Berfungsi dan bermanfaat atau tidaknya suatu ilmu tersebut bagi manusia tergantung kepada tujuan apa yang diinginkan dan untuk apa ilmu tersebut digunakan oleh manusia.

\section{F. Daftar Pustaka}

Burhanudin Salam, Pengantar Filsafat, Jakarta: Bumi Aksara, 2009.

Harun Nasution, Filsafat Agama, Jakarta: Bulan Bintang, 1997.

-----, Falsafah dan Mistisisme dalam Islam, Jakarta: Bulan Bintang, 1973.

-----, Pembaharuan dalam Islam: Sejarah Pemikiran dan Gerakan, Jakarta : Bulan Bintang, 1975.

Jujun S. Suria Sumantri, Filsafat Ilmu Sebuah Pengantar Populer, Jakarta: Sinar Harapan, 1990. 
Mahdi Ghulsyani, Filsafat Sain menurut Al-Qur'an, Bandung: Mizan. 1998.

Nurcholish Madjid, Kaki Langit Peradaban Islam, Jakarta: Paramadina, 1997.

Osman Bakri, Hirarki Ilmu, Bandung: Mizan, 2000.

Patrick, George Thomas White, Introduction ti Philosophy, London: Tp, 1986.

Ramayulis dan Samsul Nizar, Filsafat Pendidikan Islam, Jakarta: Kalam Mulia, 2009.

Sidi Gazalba, Sistematika Filsafat, Jakarta: Bulan Bintang, 1992.

Sutriono dan Rita Hanafi, Filsafat Ilmu dan Metodologi Penelitian, Yogyakarta: Andi Offset. 2007.

Uhar Suhar Saputra, Filsafat Ilmu, Universitas Kuningan. 2004

Widhia Fithri, Wacana Filsafat Ilmu, Padang: Azka. 2004 